\title{
Unstable banking
}

\section{Citation}

Shleifer, Andrei, and Robert W. Vishny. 2010. “Unstable Banking." Journal of Financial Economics 97 (3) (September): 306-318. doi:10.1016/j.jfineco.2009.10.007.

\section{Published Version}

doi:10.1016/j.jfineco.2009.10.007

\section{Permanent link}

http://nrs.harvard.edu/urn-3:HUL.InstRepos:33077921

\section{Terms of Use}

This article was downloaded from Harvard University's DASH repository, and is made available under the terms and conditions applicable to Open Access Policy Articles, as set forth at http:// nrs.harvard.edu/urn-3:HUL.InstRepos:dash.current.terms-of-use\#OAP

\section{Share Your Story}

The Harvard community has made this article openly available.

Please share how this access benefits you. Submit a story.

\section{Accessibility}




\section{NBER WORKING PAPER SERIES}

\section{UNSTABLE BANKING}

Andrei Shleifer

Robert W. Vishny

Working Paper 14943

http://www.nber.org/papers/w14943

\section{NATIONAL BUREAU OF ECONOMIC RESEARCH \\ 1050 Massachusetts Avenue \\ Cambridge, MA 02138}

May 2009

Harvard University and the University of Chicago, respectively. We are grateful to Shai Bernstein and Josh Schwartzstein for excellent research assistance, and to Malcolm Baker, Effi Benmelech, Olivier Blanchard, John Campbell, Douglas Diamond, Eugene Fama, Nicola Gennaioli, Francesco Giavazzi, Jacob Goldfield, Oliver Hart, Steven Kaplan, Anil Kashyap, Stavros Panageas, Richard Posner, Raghuram Rajan, Amit Seru, Jeremy Stein, Amir Sufi, Lawrence Summers, and Luigi Zingales for helpful conversations. The views expressed herein are those of the author(s) and do not necessarily reflect the views of the National Bureau of Economic Research.

NBER working papers are circulated for discussion and comment purposes. They have not been peerreviewed or been subject to the review by the NBER Board of Directors that accompanies official NBER publications.

(C) 2009 by Andrei Shleifer and Robert W. Vishny. All rights reserved. Short sections of text, not to exceed two paragraphs, may be quoted without explicit permission provided that full credit, including (C) notice, is given to the source. 
Unstable Banking

Andrei Shleifer and Robert W. Vishny

NBER Working Paper No. 14943

May 2009

JEL No. E32,G21,G33

\begin{abstract}
We propose a theory of financial intermediaries operating in markets influenced by investor sentiment. In our model, banks make loans, securitize these loans, trade in them, or hold cash. They can also borrow money, using their security holdings as collateral. We embed such banks in a stylized financial market, in which securitized loans may be mispriced, and investigate how banks allocate limited capital among the various activities, as well as how they choose their capital structure. Banks maximize profits, and there are no conflicts of interest between bank shareholders and creditors. The theory explains the cyclical behavior of credit and investment, but also accounts for the fundamental instability of banks operating in financial markets, especially when banks use leverage.
\end{abstract}

\author{
Andrei Shleifer \\ Department of Economics \\ Harvard University \\ Littauer Center M-9 \\ Cambridge, MA 02138 \\ and NBER \\ ashleifer@harvard.edu \\ Robert W. Vishny \\ Booth School of Business \\ The University of Chicago \\ 5807 South Woodlawn Avenue \\ Chicago, IL 60637 \\ and NBER \\ vishny@ChicagoBooth.edu
}




\section{1: Introduction}

We propose a theory of financial intermediaries operating in markets influenced by investor sentiment. In our model, banks make loans, securitize these loans, trade in them, or hold cash. They can also borrow money, using their security holdings as collateral. We embed such banks in a stylized financial market, in which securitized loans may be mispriced, and investigate how banks allocate limited capital among the various activities, as well as how they choose their capital structure. Banks maximize profits, and there are no conflicts of interest between bank shareholders and creditors. The theory explains the cyclical behavior of credit and investment, but also accounts for the fundamental instability of banks operating in financial markets, especially when banks use leverage.

In this model, banks that cannot securitize loans smooth their lending over time. When banks participate in financial markets, however, they respond to investor sentiment. Banks use their scarce capital to co-invest in newly securitized loans when asset prices are high, and to buy or hold onto distressed securities when asset prices are low. Expanding the balance sheet to securitize is so profitable in good times, however, that banks borrow short term and accept the risk of having to liquidate their portfolio holdings at below fundamental values in bad times. Such liquidations further destabilize security prices. By stretching their balance sheets to the limit in good times, banks give up the opportunity to finance investment or buy distressed assets in bad times.

Under these circumstances, bank profits and balance sheets, as well as real investment, are highly cyclical. Investment is strictly higher with securitization than without it, but may be distorted in favor of projects available for securitization during 
bubbles. This can reduce efficiency even without any costs of cyclical fluctuations. The central message is that financial intermediation transmits security market fluctuations into the real economy; the volatility of sentiment turns into the volatility of real activity ${ }^{2}$.

Our paper is related to three broad strands of research, including work on the microfoundations of credit cyclicality begun by Bernanke and Gertler $(1989)^{3}$, work on asset liquidity, fire sales, and limited arbitrage starting with Shleifer and Vishny (1992, 1997), and work in behavioral corporate finance, initiated by DeLong et al. (1989) and Stein (1996). We attempt to unify these three strands by focusing on the role of banks in transmitting market fluctuations into the real economy.

The literature on the microfoundations of credit cycles primarily focuses on the magnification of shocks to the value of capital and their impact on credit through collateral and incentive compatibility constraints ${ }^{4}$. This approach is taken in BernankeGertler (1989), Holmstrom-Tirole (1997), Kiyotaki-Moore (1997), and Fostel and Geanakoplos (2008). Our emphasis on investor sentiment and the dynamic incentives of financial intermediaries is quite different. Shleifer and Vishny (1992) show how asset liquidity, high debt capacity, and easy credit are mutually reinforcing. Benmelech and Bergman (2009) present a multiple equilibrium model in which high collateral values, high liquidity, and high debt capacity go together. Adrian and Shin (2009) document the pro-cyclicality of leverage empirically using data on broker-dealers. Allen and Gale (2000) model an asset market bubble fueled by unexpectedly loose monetary policy.

Adrian and Shin (2008) put forward a theory of procyclical leverage and credit availability based on the optimizing behavior of financial intermediaries. In their model,

\footnotetext{
${ }^{2}$ A different view of the interaction of markets and financial intermediaries is Allen and Gale (1997).

${ }^{3}$ An older literature on cyclical credit includes Fisher (1933) and Minsky (1986).

${ }^{4}$ The foundational work on optimal debt contracts, first written in 1989, is Hart and Moore (1998).
} 
procyclical leverage comes from the focus of investment banks on Value-at-Risk. Adrian and Shin argue that volatility is countercyclical, allowing banks to take more leveraged bets when asset prices are high. Rajan (2006) stresses the role of agency problems within financial firms, distorted compensation structures, and the difficulty of understanding the riskiness of complex financial instruments in generating procyclical risk-taking. Unlike Adrian-Shin (2008) and Rajan (2006), we do not focus on the banks' incentives for risk-taking, but rather address the ways that banks can profit from changes in investor sentiment and their consequences for capital allocation over time.

Our paper is also related to the literature on asset liquidity, fire sales and limited arbitrage. Shleifer and Vishny (1992) show how asset illiquidity, defined as the inability to sell an asset for its value in best use, results from the simultaneous debt overhang facing all of the specialist buyers in a given industry. Shleifer and Vishny (1997) show how asset prices fall below fundamental values when intermediaries involved in arbitrage lose the capital of uninformed investors after poor performance. Arbitrageurs liquidate their positions in a crisis, rather than stabilize prices. Gromb and Vayanos (2002) find that arbitrageurs' trades do not optimally stabilize asset prices. Brunnermeier and Pedersen (2009) show how declines in asset values lead to increases in margins and fire sales of assets that cause further declines in asset values. They label these self-reinforcing dynamics the margin and loss spirals. He and Krishnamurthy (2008) examine the asset pricing implications of shocks to financial intermediaries. Acharya, Gale, and Yorulmazer (2009) describe how the market for rollover debt, such as asset-backed commercial paper, may experience sudden freezes. Diamond and Rajan (2009) show how the fear of future fire sales keeps banks from lending. 
Finally, our paper is related to the extensive literature on behavioral corporate finance. Baker and Wurgler $(2002,2004)$ show how firms cater to investor sentiment through their dividend and capital structure policies. We use related ideas to understand the behavior of banks. Of particular relevance in this literature is the relationship between the mispricing of assets and the real investment by firms, an issue made prominent by Keynes (1936) and analyzed explicitly by Stein (1996). Baker, Ruback, and Wurgler (2007) identify two strands of evidence on this issue. An earlier strand investigated whether investment is sensitive to stock prices over and above the direct measures of marginal product of capital. The results of these studies have been mixed. ${ }^{5}$ The more recent empirical studies identify episodes of mispricing directly using proxies. These papers find stronger evidence of the effect of mispricing on real investment. ${ }^{6}$

Another question is whether the impact of mispricing on real investment is good or bad for efficiency (see De Long et al. 1989). Farhi and Panageas (2006) conclude that while overvaluation can lead to negative NPV investments, it may also help overcome the underinvestment problem stemming from financial constraints. Ventura (2003) and Farhi and Tirole (2008) come to similar conclusions in models with rational bubbles.

In reviewing all this research, we have not uncovered any work that focuses on the specific role played by banks in transmitting the fluctuations in investor sentiment into the real economy. Likewise, in the thorough survey of financial intermediation by Gorton and Winton (2003), there is little discussion of the role of investor sentiment.

\footnotetext{
${ }^{5}$ Barro (1990) finds that stock prices exert a strong independent influence on investment. Morck, Shleifer, and Vishny (1990) and Blanchard, Rhee, and Summers (1993) find that the effect of stock prices on investment is small after controlling for fundamental determinants of marginal profitability of investment. ${ }^{6}$ See, e.g., Baker, Stein, and Wurgler (2003), Lamont and Stein (2006), and Polk and Sapienza (2009).
} 
In Section 2, we present our model. Section 3 considers the case in which banks can participate in financial markets by securitizing loans, but cannot borrow. Many of our central results emerge in this simplified case. Section 4 examines what happens when banks can borrow and further expand their balance sheets when they face good opportunities. Many of our findings on instability become more extreme. Section 5 focuses on the endogenous determination of security prices. It shows that bank instability is closely associated with financial market instability, and that the two reinforce each other. Section 6 brings the findings together by considering the possible relevance of our results for the current financial crisis, as well as for appropriate policy interventions.

\section{2: The model}

We consider a model with three periods: 1,2 , and $3 . \quad$ The model is highly stylized, in that we do not derive optimal financial contracts, but rather rely on previous work to assume a reduced form version of these contracts. We then investigate the consequences of such contracts for market equilibrium. For stark focus, we examine the model with no fundamental risk to investment, and the risk-free interest rate of zero.

\section{Projects}

Real activity in the model consists of projects, which become available in periods 1 and 2, and all pay off in period 3. Each project costs $\$ 1$ to undertake. Through most of the paper, we consider identical projects. When started at $t=1$, these projects pay off a known amount $\mathrm{Z}>1$ in $t=3$ for certain. When started at $t=2$, these projects pay off the 
same known amount $\mathrm{Z}$ in the same $t=3$ for certain. The only reason to have both period 1 and period 2 projects pay off in period 3 is to avoid having period 4. Period 1 projects are long term, and do not pay off until time 3. The supply of projects costing $\$ 1$ and yielding $\mathrm{Z}>1$ is infinite, so their realization is only constrained by finance.

Screening or monitoring by an informed intermediary is required to separate these projects from the bad ones with $Z<1$. All projects must therefore be financed by banks. When a bank finances a $\$ 1$ project, it collects an up-front fee $f$ from the entrepreneur, and a certain repayment of $\$ 1$ at $t=3$. We assume that the entrepreneur and the bank split the surplus from the project, so $f=\alpha \cdot(Z-1)$ with $0 \leq \alpha \leq 1$. For simplicity, we assume that the entrepreneur pays the fee from his personal funds.

We occasionally consider the case where, at both time 1 and time 2, the projects are not all identical, but there are high $(\mathrm{H})$ and low $(\mathrm{L})$ projects, which all cost the same \$1, but pay off $Z_{H}$ and $Z_{L}$ with $Z_{L}<Z_{H}$ and $f_{L}<f_{H}$. We assume that the number of high projects is limited to $N_{H}$ each period, but that the supply of low projects is infinite.

\section{Banks}

All financing in the model is done by banks. The representative bank comes into period 1 with $E_{0}$ in equity. We do not consider deposits, or bank runs by depositors as in Diamond and Dybvig (1983), although these could be added. Let $N_{t}$ be the number of new projects the bank finances at time $t$, with $t=1,2$. Let $E_{t}$ be the bank's equity at the end of time $t=1,2,3$, where $E_{0}$ is equity at the very start. 
The bank can use its resources in several ways. First, it can hold cash. We denote by $C$ the amount of cash it holds at the end of period 1 . Under our assumptions, the bank never chooses to hold cash at time 2 because there are no opportunities arising at time 3 . The bank can also purchase securities, as we discuss below. Finally, it can lend money for projects, in which case it collects the fee up front and receives the repayment of $\$ 1$ for certain at time 3 , since projects are assumed to be riskless and the interest rate is zero.

The bank can do one of two things with these project loans. It can keep them on its books, which we refer to as traditional lending. Or, alternatively, the bank can securitize these loans and sell them off in the financial market ${ }^{7}$. In our model, securitization is simply the sale in the market of cash flow claims that would otherwise be held by banks. We do not model packaging and tranching as part of securitization, so in our model securitization looks a lot like loan syndication. We simply assume that each individual loan to a firm can be sold off in the market, and represents a claim to $\$ 1$ for certain at time 3. In our model, all loans are the same. Packaging and tranching would amplify the effects modeled in our paper if they cater to investor demand and thereby improve the terms on which banks can sell securities or borrow against them (because, for example, engineered securities are rated AAA $)^{8}$. Such securitization would allow the bank to more profitably expand its balance sheet in response to market opportunities.

Our central assumption about securitization is that when the bank sells off a loan in the market, it must initially keep a fraction $d$ of the loan on its own books. We can

\footnotetext{
${ }^{7}$ We do not allow banks to securitize commitments to make future loans.

${ }^{8}$ In our model, one role of the banks is to identify asset classes with abnormally high demand from investors and then structure the loans to borrowers and the securitized cash flow claims on those loans to cater to investor demand. Rather than delegate all their investment to the banks as in the model of Diamond (1984), investors in our model have definite preferences over assets. Presumably, this is because they are mostly institutions themselves and are run by professionals with investment expertise.
} 
think of $d$ as the bank's necessary initial skin in the game when it securitizes loans. If $N$ projects are financed and the corresponding loans are securitized, the bank must hold $d N$ of these securities on its balance sheet at the time of the underwriting. We assume that the bank does not need to hold on to these securities for more than one period.

We do not derive $d$ from first principles, but a substantial literature justifies this assumption. Gorton and Pennacchi (1995) ask: when would outside investors be willing to buy loans from banks with presumably superior information? In their model, incentive compatible contracts involve the bank retaining a portion of the loan or else guaranteeing the loan against default. The authors then test this model using data on actual loan sales contracts. They find that the most common arrangement involves the bank retaining a portion of all loans that are sold to outside investors and that this portion is greater for riskier categories of loans. Sufi (2007) provides more recent corroborative evidence for the skin in the game assumption using data from the syndicated loan market. Holmstrom and Tirole (1997) derive conditions under which outside investors will lend alongside banks on more favorable terms than they would without bank participation. The optimal incentive compatible contract involves the bank retaining a minimum fraction of the loan so that it has sufficient incentive to monitor the borrower.

These papers support our assumption that banks must have "skin in the game" by retaining a minimum fraction of loans sold to outside investors. Of course, more complex implicit contractual arrangements are also common, as discussed by Gorton and Souleles (2007) in the case or credit card securitizations and by Brunnermeier (2009) with respect to liquidity backstops provided by sponsors of Structured Investment Vehicles (SIVs). But $d$ can serve as a summary measure of these arrangements. 
Empirically, required skin in the game may be lower when asset prices are high, possibly because investors are less cautious about information asymmetries and agency problems when they are optimistic. This alternative assumption would only strengthen our results.

When the bank securitizes a loan, it can sell the securities it does not retain in the market. We denote by $P_{t}$ with $t=1,2$ the price of the securities are time $t$. In the case of identical projects, all securities are obviously identical. Even with heterogeneous projects, we can assume that security prices are all identical, since each security corresponds to a loan of $\$ 1$ that pays off $\$ 1$ for sure at time 3, regardless of the project.

Prices of securitized debt can deviate from the rational price of 1 because of investor sentiment. We assume that sentiment affects all securitized debt by the same amount, but do not consider inefficiencies in other markets such as bank stocks. Although sentiment here affects one particular asset class (securitized debt), it can come from a variety of sources, such as shifts in psychology, regulatory rules, or otherwise fundamental payoff-unrelated demand for a particular asset class. For example, if some investors such as insurance companies or money market funds demand AAA-rated bonds for reasons beyond the fundamental economics of payoffs, and are willing to pay substantially more for such bonds than for almost equally safe bonds, we think of this as investor sentiment. Such demand can be fueled by loose monetary policy, which lowers risk-free rates and may cause investors seeking yields to overpay for higher yielding securities still perceived to be safe. Demand can also be boosted by evidence of a favorable recent default history, as when Drexel sold large amounts of high-yield corporate bonds in the LBO boom of the 1980s (Kaplan and Stein 1993), or when house price appreciation made mortgage defaults relatively rare. At the other end of the 
spectrum, bad fundamental news can cause investors to dump securities when they lose confidence in their valuation models (Caballero and Krishnamurthy 2008).

Until Section 5, we take security prices as exogenous, on the assumption that arbitrage is limited and does not drive those prices to the fundamental value of 1 (DeLong et. al 1990, Shleifer and Vishny 1997). We abstract from uncertainty about future security prices because it is not central to our main points. Indeed, a bank uncertain of when security prices will fall might be even more willing to originate loans at time 1. For simplicity, we focus on the case in which $P_{2}<P_{1}$ (and in particular $P_{1}>1$ and $P_{2}<1$ ), and the bank actually knows $P_{2}$. We are thus looking for conditions under which the bank expands its balance sheet at time 1 even when it knows that good times are about to end. We assume that the bank understands the model, including the fact that the fundamental value of securities is 1 at all times (recall that the interest rate is zero) ${ }^{9}$.

The bank has an incentive to securitize loans only if $f>1-P_{1}$, since it needs to supply $\$ 1$ to the entrepreneur. We assume that the banks collect nothing in fees from security buyers, so that from the point of view of fee collection, securitization and traditional lending are identical per loan. We also assume, to simplify matters, that when the bank sells loans at a price $P_{1}>1$, it collects profits $\left(P_{1}-1\right)(1-d)$ per loan from security buyers, and immediately distributes these profits, as well as the fees obtained from the entrepreneurs, as dividends or employee compensation.

This is a strong assumption, since retaining profits would enable the bank to buy underpriced securities, or avoid liquidation, at time 2. Nonetheless, we think it is

\footnotetext{
${ }^{9}$ We can alternatively model banks as having adaptive expectations and learning quickly that loans can be resold at prices at or above their face values. Such banks need not have perfect foresight, but simply not expect to lose too much money should market conditions deteriorate. The banks in our model are much more cautious, in that they both foresee the price decline at time 2, and recognize its economic effects.
} 
appropriate. First, competitive pressures, in particular those for key employees, might force the banks to distribute a large share of profits as compensation. Second, perhaps as importantly, if the bank retains profits, its profit-maximizing policy, as we show below, is not to keep them in cash, but instead to instantaneously recycle them to finance and securitize additional projects. For tractability, we do not allow for such recycling of profits within a period. The key point is that profit-maximizing banks will not retain profits as a safety cushion in our model, which contributes to instability.

Just as the bank can profitably underwrite and sell securities when prices are at least equal to 1 , the bank that has capital can buy securities. We are interested in the case in which $P_{2}<1$, so it might be in the interest of the bank to buy securities at $\mathrm{t}=2$, which pay off $\$ 1$ at $t=3$. We also need to consider, for this reason, the question of whether the bank wants to hoard cash at time 1 so as to be able to buy securities in distressed markets.

The final question is how the bank finances its operations, in addition to its equity cushion (recall that we do not have deposits in the model). Our central assumption is that the bank can borrow in financial markets using the securities it holds as collateral. We denote by $L_{t}$ the stock of short term borrowing by the bank from the market at time $t=1$, 2. Because the lending is collateralized, we assume that the lenders always liquidate collateral quickly enough to be left whole, so these loans are safe and bear the interest rate of zero. To keep themselves safe, lenders to the bank insist that at all times it must maintain a haircut $h$ in the form of securities on its debt; that is, $L_{t}=(1-\mathrm{h}) \cdot$ collateral . We take $h$ to be constant. If, as argued by Brunnermeier and Pedersen (2009) and Adrian and Shin (2009), haircuts are countercyclical, the instability described in our paper becomes more extreme. 
Our specification of $h$ captures the kind of short-term collateralized borrowing arrangements, such as asset-backed commercial paper and repo transactions, which have become increasingly prevalent (see Adrian and Shin 2008, 2009 and Gorton 2008). In these transactions, banks often borrow on a safe haircut that allows lenders to liquidate the collateral before its value falls below the value of the loan. Consistent with Williamson (1988) and Shleifer and Vishny (1992), securitization encourages this type of borrowing by making the assets retained on bank balance sheets more liquid and redeployable, thereby supporting higher leverage. Indeed, an important side benefit of "true" securitization, with packaging and tranching, is that AAA securities can be used as collateral with very low haircuts. Both security buyers such as leveraged hedge funds and banks underwriting securities benefit from low haircuts.

Because the market prices and liquidity of securities fluctuate over time, the collateralized lending arrangements are typically short-term. Any borrower seeking to make these loans longer term would presumably have to accept a higher haircut, thereby decreasing its debt capacity (as well as pay higher interest rates if there is a risk of default). Long term debt would thus be more expensive. An alternative view is that short term debt is a disciplinary device against agency problems (Diamond and Rajan 2001). We suggest instead that banks borrow short term because of redeployable mark-to-market collateral created by securitization, and the profitability of borrowing and securitizing as much as possible in the boom. We also assume, but do not model explicitly, that banks choose not to raise equity at time 2, perhaps for the usual adverse selection reasons.

The principal consequences of bank borrowing in our model is that, should the price of securities fall at time 2, the bank might have to liquidate some of its portfolio of 
securities to maintain the haircut. We denote by $S$ the number of securities the bank sells at time 2. Of course, we also need to consider the case in which the bank chooses to buy more securities at time 2 , in which case $S<0$. Security liquidations can quickly wipe out the bank's equity (remember the lenders to the bank never lose money), but also create downward price spirals in securities. As we show below, although securitization makes banking highly cyclical even without leverage, leverage exacerbates the volatility.

\section{Organization of the paper}

In section 3, we consider the case of $h=1$, so $L_{1}=L_{2}=0$; the bank cannot borrow in the market. We compare $d=1$, which corresponds to traditional lending where the bank keeps the loans on its books, with $d<1$, which refers to securitization. We ask when it pays the bank to finance everything it can at $t=1$ and save no cash, even when more high projects become available at $t=2$. We start with $P_{1}=1$, but then turn to $P_{1}>1$.

In section 4 , we consider the case of $h<1$, so the bank can borrow in the market to expand its activities. In this case, we examine the liquidation of the securities portfolio at $t=2$ when $P_{2}<1$. We again look at both $P_{1}=1$ and the bubble, with $P_{1}>1$. In section 5, we examine the endogenous determination of $P_{2}$.

Throughout the paper, we use a numerical example with $d=.2, h=.2, P_{1}=1.1$, $P_{2}=.9, f=f_{H}=.09, f_{L}=.08$. We assume a relatively high $h$ because we are thinking of relatively long periods and lending against risky securities, such as mortgages. 


\section{3: Securitization without Bank Leverage}

In this section, we consider the case of no bank leverage: $h=1, L=0$. We first deal with the case of $P_{1}=1$, so there are no speculative gains to the bank from underwriting securities. To illustrate the main ideas, we also assume that the bank knows that security prices will fall below 1 at $t=2$, and even knows the exact value of $P_{2}<1$. We are interested in understanding under what circumstances the bank uses its balance sheet to finance securitization even when it knows that the good times will not last and the market will shortly crash.

Traditional lending: $d=1$.

To fix ideas, we begin with the case of traditional lending, in which the bank cannot sell off project loans in the market. Suppose all projects available at $t=1$ and $t=2$ are identical. If the bank uses all of its balance sheet in period 1, it lends out all of $E_{0}$ to finance $N=E_{0}$ projects, and keeps all of them on its books. The bank collects $E_{0} f$ as fees, and distributes these profits as dividends (or employee compensation). Since the interest rate is equal to zero, however, it costs the bank nothing to save up half of its capital until $t=2$, finance half of the projects, and collect half of the fees, in period 2 . Regardless of how the bank spreads out its financing, it gets its money back at $t=3$. The central point is that, as we have set up the model, there is no reason for cyclicality of traditional lending. If we assume (as we do a bit later) that there is a limited number of high projects each period, the bank has an incentive to smooth its lending over time.

Securitization $d<1$ 
Now suppose that the bank can securitize its loans. Then, if it uses up all of its capital at $t=1$, it can finance $N=\frac{E_{0}}{d}$ projects, and keep $d N=E_{0}$ in securities on its books as skin in the game. Obviously, $\frac{E_{0}}{d}>E_{0}$, so the number of projects financed, and the balance sheet, expand. Also, profits at $t=1$ are now $f \frac{E_{0}}{d}>f E_{0}$. The bank has greatly increased its profitability through securitization. At time 2, security holders and the bank suffer capital losses if $P_{2}<1$. But these losses lead to no liquidation and are economically irrelevant. Everyone can wait until $t=3$, to collect $\$ 1$ per loan. The bank suffers equity erosion at $t=2$, but it is inconsequential.

We need three additional conditions. First, the bank must not want to securitize at $\mathrm{t}=2$ when $P_{2}<1$. Second, the bank must not want to sell its securities at $P_{2}$ and use the proceeds for lending to new projects. The condition for the bank not to sell at $t=2$ is $\frac{1-P_{2}}{P_{2}}>f$, which means that keeping securities for capital gains at $t=3$ is more profitable than selling them and collecting fees from new firms ${ }^{10}$. Note that $f<1-P_{2}$ is sufficient for both of these to hold, and they hold in our example. Third, we need to check that the bank does not wish to hoard cash at $t=1$ to invest in undervalued securities at $t=2$; we work out the condition for this to be the case below.

If the bank does not want to wait when it expects securitization opportunities to evaporate, it uses - even in this simple example - all of its balance sheet to make securitized loans in period 1. Indeed, there is no new investment at time 2. As a

\footnotetext{
${ }^{10}$ It may even be the case that, due to the scarcity of capital, $f$ in period 2 is higher than in period 1 , and involves giving the bank all of the surplus. This would make the sufficient condition be $f=Z-1<1-P_{2}$.
} 
consequence, the bank earns all of its fees at time 1, and none at time 2 . In the model as we have specified it so far, such extremely cyclical activity is efficient, since projects add social value, and the more of them are financed, the better. Securitization makes the bank's profits, as well as real investment, more cyclical than traditional lending, but the benefit of such cyclicality is more activity. Below we show that this efficiency conclusion is not general, however.

With the bank holding on to its securities at $t=2$, its balance sheet is cyclical in so far as security prices fluctuate, and the portfolio is marked to market. But there is no particular economic reason to mark the portfolio to market, since the value of the portfolio serves no economic function without bank leverage. We next consider the robustness of this simple example to several perturbations.

\section{Heterogeneous Projects:}

With identical projects, there is no reason for the bank to smooth its financing, so securitization creates strong pressures for cyclicality. Suppose, alternatively, that the bank has access to some high payoff projects every period, but not enough so it can stick to only funding those at time 1 . Will it pay the bank to wait with some cash until $t=2$ when more high payoff projects become available?

When $d=1$ and there is no securitization, the bank will smooth its investments to benefit from good projects that become available for financing in period 2. Recall that $N_{H}$ is the number of high payoff projects per period. If $E_{0} \leq 2 N_{H}$, the bank will finance

$\frac{E_{0}}{2}$ high projects each period - complete smoothing. If $E_{0}>2 N_{H}$, the bank will finance all high projects, and some low projects, each period, again complete smoothing. (More 
accurately for the second case, the bank will always smooth high projects and is indifferent to smoothing low projects.)

Suppose $d<1$ and there is securitization at $\mathrm{t}=1, E_{0}>2 N_{H}$, and $P_{2}<1-f_{H}$, so the bank does not want to securitize at $t=2$. If the bank does not save $N_{H}$ until $t=2$ and instead finances and securitizes everything it can at $t=1$, then its profits are given by:

$$
\pi_{\text {no save }}=N_{H} \cdot f_{H}+\left(\frac{E_{0}}{d}-N_{H}\right) f_{L}
$$

If the bank saves $N_{H}$ and finances new high projects at $t=2$, its profits become:

$$
\pi_{\text {save }}=\left(\frac{E_{0}-N_{H}}{d}-N_{H}\right) f_{L}+2 N_{H} f_{H}
$$

The condition for the bank using all of its balance sheet to lend to projects at $t=1$, and saving up nothing for $t=2$, becomes:

$$
\pi_{\text {no save }}>\pi_{\text {save }} \text { iff } \frac{f_{L}}{d}>f_{H} .
$$

Unless high projects are hugely better than low ones, this condition is likely to hold. The benefits from funding more projects through securitization are so high that the bank foregoes funding some good ones in bad times.

The bank's policy obviously makes investment more cyclical than with $d=1$, but this is still efficient as long as $\frac{Z_{L}}{d}>Z_{H}$. So if $f_{L}=Z_{L}-1$ and $f_{H}=Z_{H}-1$ (bank extracts all surplus from firms), cyclical investment is efficient. It is true that some high projects are given up at time 2, but so many more low projects are financed at time 1 , 
when securitization opportunities are available, that the cyclicality is efficient. The efficiency result comes from the alignment of the bank's profitability and social efficiency, which is special to the case of $P_{1}=1$ and breaks down when $P_{1}>1$, as we discuss below. With cyclical investment, the profits of the bank are enormously cyclical, since it collects all its fees in the first period, and none in the second. The balance sheet of the bank is, as before, cyclical because prices of securities fluctuate and fall in the second period. However, without leverage, the number of securities on the bank's books could as well be constant over time, so there is no cycle there.

\section{Saving for Tomorrow}

A key question to address to complete the description of equilibrium is whether banks would hoard some cash for the future at $t=1$ when they expect security prices to fall, so that they can buy undervalued securities. Continue to assume that the bank knows that $P_{2}<1$, and ask under what conditions it nonetheless commits all capital to securitization at $t=1$. We go back to the case of homogeneous projects.

If the bank uses all its capital at $\mathrm{t}=1$ for securitization, its profits are $N f=\frac{E_{0}}{d} f$.

If the bank saves cash $C$ for the second period and invests it in undervalued securities, then its profits are $\frac{E_{0}-C}{d} f+\frac{C}{P_{2}}\left(1-P_{2}\right)$. The condition for the bank not to hoard any cash, then, is given by

$$
\begin{gathered}
\frac{E_{0} f}{d}>\frac{E_{0} f}{d}-\frac{C f}{d}+C\left(\frac{1-P_{2}}{P_{2}}\right) \text { or } \\
\frac{f}{d}>\frac{1-P_{2}}{P_{2}} .
\end{gathered}
$$


The profit function in this model is linear in $C$, so the bank is always at a corner, with either $C=0$ or $C=E_{0}$. It either saves everything or nothing.

In our model, the condition for not hoarding cash is likely to hold, since $d$ is small and $P_{2}$ is only slightly below 1 . So if, as in our numerical example, $P_{2}=.9, f=.09, d=.2$, then $\frac{f}{d}=.45$ and $\frac{1-P_{2}}{P_{2}} \approx .11$. There is a strict preference for not holding cash as long as prices are not expected to crash. The bank takes full advantage of securitization and does not leave any gunpowder dry. Putting this and the previous results together, the model suggests that because securitization profits are so high, the bank does not save money for the future to either finance projects or to invest in undervalued securities. It extends itself to the maximum and uses its balance sheet for securitization. This is not a consequence of herding or irrationality, but rather of enormous liquidity in the market. The times are so good that the bank wants to expand its balance sheet to the maximum, and fund as many projects as it can as fast as it can.

This analysis has a number of implications. First, it shows how investor sentiment, through securitization, infects banking and leads to cyclicality of profits, of investment, and at least of the market value of the balance sheet. Banks use up all their capital in booms knowing full well that a crisis will come and that they will suffer (at least book) losses. But they realize that there is so much money to be made during booms that they should nonetheless extend themselves fully.

Second, we can ask what happens if an unanticipated $\$ 1$ of equity is injected into the bank at $t=2$, so it all of a sudden has $\$ 1$ of spare capacity. In this case, the return from project finance is $f$, while the return from buying traded securities is $\frac{1-P_{2}}{P_{2}}$. The bank 
will commit the extra dollar to whichever one is more profitable, and we have assumed that it is more profitable in bad times to invest in securities than to lend directly.

This observation has a major implication: if the dislocation of asset prices is severe enough, the bank allocates the capital windfall to buying underpriced securities no capital flows to new investment. This will continue happening until security prices stabilize. When the markets are dislocated, the rational strategy of the bank is to engage in proprietary trading rather than to finance real investment.

\section{Bubbles}

We finally consider what happens when $P_{1}>1$. Suppose that the bank finances and securitizes all the projects it can. It must keep $N d$ securities as skin in the game, so $N d=E_{0}$. Without leverage, the bank makes no gains from high security prices in terms of expanding its balance sheet. However, period 1 distributed profits are now given by: $\left(P_{1}-1\right)(1-d) N+N f$, which is higher than $N f$ when $P_{1} \geq 1$.

The incentives to save cash for undervalued assets, or to wait for the next round of good projects, are now even weaker than before. There is even more cyclicality of profits and balance sheet because of the greater fluctuation in prices over time. There are still no economic consequences of the decline in the balance sheet at time 2, however.

Perhaps the most interesting change in the model with bubbles concerns the efficiency of investment. Suppose that there are two kinds of projects each period: high ones with $Z_{H}>1$ (and a positive fee) and low ones with $Z_{L}=1$ (and a zero fee), and that the high ones are in limited supply. The assumption that low projects are zero net present value is made only to illustrate the point starkly. Suppose that all loans - for both high 
and low projects -- can be securitized at $\mathrm{t}=1$ and sold off at $P_{1}>1$, but that the price falls below 1 at time 2 . So long as $P_{1}$ is high enough, it pays the bank to use all of its balance sheet for securitization at time 1 , including funding the low projects, and to make no loans at time 2, including to the high projects. This is clearly less efficient from the social viewpoint than smoothing the financing over time, at least to the point where all the high projects are financed. In this model, bubbles break the link between social efficiency and bank profits, and hence create an inter-temporal distortion in favor of excessive financing of less attractive projects during booms.

This distortion becomes even larger if projects vary by the amount of skin in the game they require for securitization, and if some efficient projects also happen to have high $d$ 's. For example, some corporate loans, while financing particularly socially desirable investments, might be harder to securitize than some more homogeneous loans. In this case, bubbles again create a bias toward financing securitizable investments, and hence can lead to distortions. Indeed, with a shortage of securitizable projects, we can have $\mathrm{Z}<1$ and still the project is financed when $P_{1}$ is sufficiently above 1 . This would require a rebate to borrowers $(f<0)$, as when banks offer homeowners teaser rates.

\section{Summary}

The analysis without bank leverage yields five significant conclusions:

1) Relative to direct lending, securitization raises the level of investment, but also its cyclicality, as well as that of balance sheets and profits. It transmits fluctuations in investor sentiment into the real economy through the banking sector. 
2) There is a built in bias toward funding projects that can be securitized at favorable prices, and away from projects that cannot be securitized as easily (either because they come up in bad times or because they require the banks to hold more skin in the game). With bubbles, this leads to inefficiencies in what is being financed. These inefficiencies may outweigh the welfare gains from securitization.

3) Banks rationally pursue profits in booms, and accept book losses in busts, because money making opportunities in booms are so attractive.

4) In busts, banks hold on to securities because of expected capital gains, rather than liquidate them and make fresh loans to new projects.

5) Attempts to help out banks in bad times may help stabilize asset prices, but not real investment. Banks will engage in proprietary trading, not lending, until the price of distressed assets comes close enough to fundamental value.

\section{4: Securitization and Investment with Leveraged Banks}

Suppose that the bank holding securities can borrow in the market using them as collateral. We assume that the debt is short term, and security prices do not move too fast, so lenders can always liquidate the collateral fast enough to be repaid in full. In this case, the interest rate on the debt is zero. The mechanism of making the debt safe is the haircut $h$ which the borrower must meet for the loan to stay in place. When the bank commits all of its resources, i.e., all of its debt and equity, at time 1 to security holdings (to be used as collateral), the definition of the haircut implies that: 


$$
\frac{E_{1}}{E_{1}+L_{1}}=\frac{E_{2}}{E_{2}+L_{2}}=h \text { as long as } L_{i}>0 .
$$

When the period 2 price falls, securities must be liquidated to maintain the haircut.

We begin with $P_{1}=1$ again, and consider what happens if the bank expands its balance sheet to the maximum, i.e., does not hoard any cash for $t=2$. We later provide the conditions for this to be the profit-maximizing policy for the bank.

If the bank uses up its entire balance sheet, which now consists of both equity and short term debt, for securitization purposes, the skin in the game condition with $P_{1}=1$ is:

$$
E_{0}+L_{1}=N d
$$

The condition for the bank not to exceed its borrowing capacity at $t=1$ is:

$$
\frac{E_{1}}{E_{1}+L_{1}}=h
$$

Solving for the equilibrium number of projects, we obtain:

$$
N=\frac{E_{0}}{d h}
$$

Here collateral is $N d=\frac{E_{1}}{h}$ and the loan is $L_{1}=(1-h) \bullet$ collateral.

Equation (9) captures the fundamental mechanisms of balance sheet expansion in our model. The bank finances $1 / d h$ times its equity in projects. To use our numerical example, if $h=.2$ and $d=.2$, then the bank finances 25 times its equity value in projects, has a balance sheet of 5 times its equity value, and has the debt equity ratio of 4 . With a lower $h$, these numbers become higher. 
Consider next what happens at $t=2$, when prices fall and $P_{2}<1-f$. The bank obviously cannot finance loans by issuing securities. Indeed, to maintain the haircut, the bank now needs to sell securities. Suppose it sells $S$ securities, so it holds $N d-S$ securities valued at $(N d-S) P_{2}$ at the end of period 2. It uses the proceeds from selling securities to repay $P_{2} S$ of its loan, so it still owes $L_{2}=L_{1}-P_{2} S$ to the lenders. Since all the losses on the securities come from the bank's equity (lenders are at no risk), we can compute the resulting equity and haircut:

$$
\begin{gathered}
E_{2}=(N d-S) P_{2}-\left(L_{1}-P_{2} S\right)=N d P_{2}-L_{1} \\
h=\frac{E_{2}}{E_{2}+L_{2}}=\frac{N d P_{2}-L_{1}}{(N d-S) P_{2}}
\end{gathered}
$$

If we plug in $L_{1}=\frac{E_{1}(1-h)}{h}$ and $N d=\frac{E_{1}}{h}$, we obtain $h N d P_{2}-h S P_{2}=N d P_{2}-L_{1}$, so

$$
S=\frac{E_{1}}{h}\left[\frac{1-P_{2}}{P_{2}} \cdot \frac{1-h}{h}\right]
$$

The bank must liquidate the fraction $\frac{1-P_{2}}{P_{2}} \cdot \frac{1-h}{h}$ of its portfolio. When $h=1$, there is no liquidation. When $P_{2}=1-h$, the bank must liquidate everything, so assume $P_{2} \geq 1-h$, i.e. the creditors have not yet liquidated the entire portfolio.

There are several points to notice about the expression for S. The bank unwinds its portfolio very rapidly as the price falls. If $h$ rises in bad times, it unwinds the portfolio even more rapidly. We can compute some comparative statics on liquidation. First, 


$$
\frac{d S}{d h}=\mathrm{E}_{1}\left(\frac{1-\mathrm{P}_{2}}{\mathrm{P}_{2}}\right)\left(\frac{\mathrm{h}(-2+\mathrm{h})}{\mathrm{h}^{4}}\right)<0
$$

When the haircut $h$ is smaller, liquidation proceeds more quickly because leverage is higher. So if period 1 was one of very liquid markets, with low haircuts, we expect to see quick liquidations of bank portfolios even without rising haircuts. Second,

$$
\frac{d S}{d P_{2}}=\frac{E_{1}}{h}\left(\frac{1-h}{h}\right)\left(\frac{1-2 P_{2}}{P_{2}^{2}}\right)<0
$$

The larger is the price shock at time 2, the faster is the liquidation. Recall that we are only looking at modest price shocks, and do not consider large (unanticipated) shocks that precipitate complete liquidation and might even entail losses to the lenders.

Leverage changes the situation dramatically relative to the case with no leverage. So long as the full commitment of the balance sheet is an equilibrium, which it is under conditions discussed below, leverage only increases the cyclicality of real investment. But now, the bank actually liquidates a part of its portfolio when security prices fall. This means that banks destabilize security prices by selling into a falling market. Moreover, the smaller is the haircut, the bigger is liquidation and this destabilizing role. In section 5, we consider the endogenous determination of security prices.

The model illustrates the crucial maturity mismatch. Banks borrow short term to underwrite securities that finance long term projects. With mark to market accounting, they might not be able to maintain those investments on their books should the sentiment decline. Banks wish to hold on to these undervalued securities, but they are forced to liquidate by creditors. Recall that the efficient thing to do would be for the banks to sell 
their security holdings and finance new investments. But securities are underpriced, and the banks would rather own more than they can; they surely do not want to lend to firms.

We next need to establish the conditions under which full commitment of capital to securitization is equilibrium. We continue to assume that $P_{2}>1-h$, so liquidation keeps the loan safe. The first question is what happens with heterogeneous projects, and in particular whether good projects at $\mathrm{t}=2$ are sacrificed to securitization. To get at that, we compare the profit generated by using a dollar to make securitized loans to low projects at $t=1$ to the profit generated by using that dollar to make unsecuritized loans to high projects at $t=2$.

If the bank spends $\$ 1$ to make securitized loans to low projects at $t=1$, it finances $\frac{1}{d h}$ projects, holds $\frac{1}{h}$ of these projects on its books, and collects a fee of $\frac{f_{L}}{d h}$. At $t=2$, it must sell the fraction $\frac{1-h}{h} \frac{1-P_{2}}{P_{2}}$ of its portfolio at a loss $\left(1-P_{2}\right)$ to meet the haircut, which leads to a total loss of $\underbrace{\frac{1}{h}\left(\frac{1-h}{h} \frac{1-P_{2}}{P_{2}}\right)}_{S}\left(1-P_{2}\right)$. On net, its profit is:

$$
\frac{f_{L}}{d h}-\underbrace{\frac{1}{h}\left(\frac{1-h}{h} \frac{1-P_{2}}{P_{2}}\right)}_{S}\left(1-P_{2}\right)
$$

If the bank instead uses the dollar to make unsecuritized loans to high projects at $t=2$, then it finances $\frac{1}{h}$ such projects and collects an up front fee of $\frac{f_{H}}{h}$, so its profit is $\frac{f_{H}}{h}$.

Comparing the two profit levels yields the no waiting condition: 


$$
\frac{f_{L}}{d}>f_{H}+\underbrace{\frac{1-h}{h} \frac{1-P_{2}}{P_{2}}\left(1-P_{2}\right)}_{\text {cost of maintaining haircut }}
$$

The advantage of doing everything right away now diminishes by the term in curly brackets. The reason is that the bank might not be able to sustain its position through the price decline, and have to liquidate it at disadvantageous prices before the loan is paid off for certain at time 3. Because the bank might have to liquidate some or all of its position, it is now more attractive to wait even though the benefit of financing new good projects is unchanged at time 2. We can try to calibrate this equation. If the price does not fall too much, this additional term is small, and so it is still likely that there are strong incentives to go all the way at $t=1$. In particular, this equation holds for our parameter values. Bank borrowing thus leads to an even greater expansion of balance sheet at time 1 than before, and even more extreme volatility of investment.

We also need to check whether banks hoard cash so they could invest it during the slump. To do this, we compare the profit generated by using a dollar to make securitized loans to finance projects at $t=1$ to the profit generated by using that dollar to buy underpriced securities at $t=2$. If the bank makes securitized loans at $t=1$, it finances $\frac{1}{d h}$ projects, holds $\frac{1}{h}$ of these projects on its books, and collects an up front fee of $\frac{f}{d h}$. At $t=2$, it must sell fraction $\frac{1-h}{h} \frac{1-P_{2}}{P_{2}}$ of its portfolio at loss $\left(1-P_{2}\right)$ to meet the haircut, which leads to a total loss of $\underbrace{\frac{1}{h}\left(\frac{1-h}{h} \frac{1-P_{2}}{P_{2}}\right)}_{S}\left(1-P_{2}\right)$. Thus, on net, it generates a profit 


$$
\underbrace{\frac{f}{d h}-\frac{1}{h}\left(\frac{1-h}{h} \frac{1-P_{2}}{P_{2}}\right)}_{S}\left(1-P_{2}\right)
$$

If the bank instead saves the dollar, then it can buy $\left(\frac{1}{h}\right)\left(\frac{1}{P_{2}}\right)$ underpriced securities, yielding a profit

$$
\left(\frac{1}{h}\right)\left(\frac{1}{P_{2}}\right)\left(1-P_{2}\right)
$$

Comparing the two levels of profits yields the no hoarding cash condition:

$$
\frac{f}{d}-\underbrace{\left(1-P_{2}\right) \frac{1-h}{h} \frac{1-P_{2}}{P_{2}}}_{\text {cost of maintaining haircut }}>\frac{1-P_{2}}{P_{2}}
$$

This is a very similar condition to the one before. It is now more attractive than before to retain cash, because while the benefit of cash is the same, the cost of investing fully at $t=1$ is higher since the position might not be carried to full maturity. Nonetheless, to the extent that the incremental term is small, the bank might still retain no cash. In particular, the condition holds for our parameter values.

Are these conditions plausible? Recall that the bank's profit function is linear in retained cash, so it always retains everything or nothing, i.e., is at a corner. As long as the bank does not expect a massive price collapse, it keeps no cash. The benefits of committing the entire balance sheet to securitization in terms of immediate profits are only enhanced by leverage.

These conditions also shed light on the reason why banks oppose mark to market accounting. In this model, banks are forced to liquidate their positions by creditors when they cannot meet collateral requirements even though the securities are perfectly sound if 
held to maturity. The only reason for liquidation is the under-pricing of collateral in an inefficient market. If there were no mark to market and collateral was never liquidated, banks could use their balance sheets to underwrite even more securities without fear of portfolio liquidation. Absence of mark to market accounting is equivalent to extending the maturity of debt. As a consequence, absence of mark to market accounting would generally be associated with higher leverage. Holding haircuts constant, mark to market deters banks from leveraging too much, because they want to avoid liquidating collateral. Eliminate mark to market, banks would say, and we will finance more investment.

This reasoning is very partial, however. In a more general model, haircuts and interest rates would have to be higher when there is no mark to market collateral whose liquidation protects creditors. As a consequence, banks would in fact be able to borrow less and finance fewer projects. Put differently, bank leverage on good terms is only possible when creditors are protected by mark to market accounting. Banks cannot have it both ways: they cannot simultaneously be able to borrow to expand their balance sheets, and rely on non-transparent accounting to hide losses. Indeed, hedge funds can borrow precisely because they post liquid collateral to their lenders, and mark it to market so lenders can at all times ascertain the funds’ borrowing capacity.

\section{Bubbles with Leverage}

We now consider how leverage interacts with bubbles, i.e., what happens with $P_{1}>1$ ? The skin in the game condition and the haircut conditions now become:

$$
N d=E_{0}+L_{1}
$$




$$
L_{1}=\frac{E_{1}(1-h)}{h}
$$

where $E_{1}=P_{1} N d-L_{1}$. Combining equations yields $\frac{E_{1}}{h}=P_{1} N d$, so

$$
N d=\frac{E_{1}}{h P_{1}}
$$

In addition, $\frac{E_{1}}{h P_{1}}=E_{0}+\frac{E_{1}(1-h)}{h}$, so $E_{1}=\frac{E_{0} P_{1} h}{1-P_{1}(1-h)}$.

Plugging back into (22), we obtain

$$
N d=\frac{E_{1}}{h P_{1}}=\frac{E_{0}}{1-P_{1}(1-h)} .
$$

This equation explains how the balance sheet of the bank further expands in a bubble. (Note that this condition reduces to the earlier one for $P_{1}=1$.) With leverage, unlike without leverage, we have $\frac{d N}{d P_{1}}>0$. The reason is that the bank retains some securities on its balance sheet as skin in the game, but in a bubble these securities are more valuable than their cost, so the bank's equity rises. Higher equity in turn allows the bank to borrow more and to finance more projects than it could with $P_{1}=1$.

Going back to our example with $h=.2, d=.2$, and $P_{1}=1.1$, the number of projects being financed is now 40 times the initial equity, the collateral is about 8 times the initial equity, the short term borrowing is about 7 times the initial equity, the debt equity ratio with mark to market accounting is 4 , and the debt equity ratio with book value accounting 
is 7. These numbers can be blown up substantially with a lower $h$. Bubbles thus further increase the leverage and the balance sheet of the bank.

Not surprisingly, the profitability of the bank now becomes even higher during the boom. The bank has two types of profits at $t=1$. It collects $N f$ as fees from firms regardless of the mode of financing and it collects $\left(P_{1}-1\right)(1-d) N$ from security buyers when $P_{1}>1$. If the bank distributes these profits as dividends and compensation to employees, it will show enormous profitability in good times. As before, bubbles make it only more likely that the bank uses all of its balance sheet to finance securitization at $t=1$, even if it anticipates that some or all of its portfolio will need to be liquidated later. And, as before, bubbles create distortions in the financing of investments in favor of projects that are available for financing in booms and that are easier to securitize.

A final question to ask is what happens to liquidation at $\mathrm{t}=2$ after the bubble collapses. As before

$$
h=\frac{E_{2}}{E_{2}+L_{2}}=\frac{N d P_{2}-L_{1}}{(N d-S) P_{2}}
$$

Plugging in $L_{1}=\frac{E_{1}(1-h)}{h}$ and $N d=\frac{E_{1}}{h P_{1}}$ yields

$$
S=\frac{E_{1}}{h P_{1}} \frac{(1-h)}{h} \frac{P_{1}-P_{2}}{P_{2}}
$$

so the bank must liquidate fraction $\frac{(1-h)}{h} \frac{P_{1}-P_{2}}{P_{2}}$ of its portfolio at $t=2$. Finally, plugging in $E_{1}=\frac{E_{0} P_{1} h}{1-P_{1}(1-h)}$ yields 


$$
\frac{E_{0}}{1-P_{1}(1-h)} \frac{(1-h)}{h} \frac{P_{1}-P_{2}}{P_{2}}
$$

and all of the previous comparative statics go through ( $h$ smaller, sell more; $P_{2}$ lower, sell more). Also,

$$
\frac{\partial \mathrm{S}}{\partial P_{1}}>0
$$

so, fixing $P_{2}$, the greater the bubble at $t=1$ the greater the liquidation at $t=2$.

\section{Summary}

1) Leverage promotes a further expansion of balance sheets in boom times, and generally increases the cyclicality of investment and profits.

2) Leverage leads to liquidations of bank portfolios at prices below fundamental values in bad times.

3) The principal source of instability is securitization. Short term borrowing makes it worse, and may lead to much higher price volatility (section 5). But the mechanism of transmission of investor sentiment into commercial banking and the real economy is securitization.

4) The result that equity injections will not lead to any new real investment might only become stronger if prices fall further with leverage, as banks use fresh capital to pay down debt and avoid liquidating their portfolios at fire sale prices. 


\section{5: Determination of $P_{2}$}

Until now, we have discussed bank instability in light of exogenous volatility of security prices. But of course, bank instability and the sharp declines in security prices are often seen as mutually reinforcing. To deal with this issue, we need to endogenize $P_{2}$. In this section, we use a variant of the "limits of arbitrage" model of Shleifer and Vishny (1997) to endogenize prices with the banks playing the role of arbitrageurs. The key assumption of that model is that there is a downward sloping demand curve for a given security coming from the noise traders. The equilibrium price is determined by aggregating noise trader and bank demands for each security with outstanding supply.

We focus on period 2. We assume that there is only one type of project, and focus again on the equilibrium in which the bank holds no cash at the end of time 1 . We make a stability assumption that $h>d$ (Shleifer-Vishny 1997 have a similar assumption), and continue to assume that the banks do not fully liquidate their positions at time 2:

$$
1-f>P_{2} \geq 1-h
$$

To model noise trader demand, we follow Shleifer and Vishny (1997) and assume that noise traders have unlimited aggregate resources, but that their demands for individual securities are unit elastic. So when noise traders have valuations given by $1-\sigma$, where $\sigma$ is noise trader shock, their total demand for a given security is given by $\frac{1-\sigma}{P_{2}}=n_{2}\left(P_{2}\right)$. From (12), banks' demand for a given security is $d-\frac{S}{N}$, where $S=d N \frac{1-h}{h} \frac{1-P_{2}}{P_{2}}$ is the number of securities the bank sells at time 2. The condition for noise trader shock being mild enough that (28) holds is: 


$$
d+\frac{f(h-d)}{h}<\sigma<h
$$

When this condition holds, the bank's demand is:

$$
b_{2}\left(P_{2}\right)=d\left[1-\frac{1-h}{h} \frac{1-P_{2}}{P_{2}}\right]
$$

The price of each security is determined by equating the total demand of the banks and the noise traders with the total supply of each security, which is 1 :

$$
n_{2}\left(P_{2}\right)+b_{2}\left(P_{2}\right)=1
$$

We can now substitute from the demands of noise traders and banks to obtain:

$$
\frac{1-\sigma}{P_{2}}+d\left[1-\frac{1-h}{h} \frac{1-P_{2}}{P_{2}}\right]=1
$$

Solving for $P_{2}$, we obtain

$$
P_{2}=\frac{h[1+d]-d-\sigma h}{h-d}
$$

Equation (33) is the expression for the endogenous equilibrium price at time 2. The sensitivity of $P_{2}$ with respect to the noise trader shock is given by:

$$
\frac{d P_{2}}{d \sigma}=\frac{-h}{h-d}
$$


$P_{2}$ is more responsive to shocks when $d$ is large and $h$ is small. When haircuts are small and therefore leverage is high, prices are extremely sensitive to shocks. Leverage is destabilizing in this very precise sense. Indeed, when $h$ is close to $d$, as it is in our example, the market falls sharply in response to noise trader shocks and there is extreme instability. In equilibrium, the banks will actually get out of the market. In addition, the derivative of $P_{2}$ with respect to $h$ is positive, which means that, with more leverage (lower $h$ ), for a given shock, $P_{2}$ is lower. Leverage is destabilizing in this sense as well.

\section{Relationship to parameter a in SV:}

As a final step in the analysis of the model with endogenous prices, we compare our results to those in Shleifer and Vishny (1997). In that model, we did not focus on leverage, but rather modeled the idea that the arbitrageurs' funds under management at time 2 are an increasing function of their performance between time 1 and time 2. As a consequence, when noise trader pessimism deepened at time 2, arbitrageurs lost funds under management precisely when noise trader sentiment deteriorated.

Shleifer and Vishny modeled the responsiveness of funds under management to past performance using a parameter $a$, which, in the notation of our current model would be defined as follows (thinking of banks as arbitrageurs):

$$
\begin{gathered}
P_{2} b_{2}\left(P_{2}\right)=d\left(1-a\left(1-P_{2}\right)\right), \text { or } \\
b_{2}\left(P_{2}\right)=\frac{d\left(1-a\left(1-P_{2}\right)\right)}{P_{2}}
\end{gathered}
$$

For comparison, recall that, in our model, the demand from banks is given by: 


$$
b_{2}\left(P_{2}\right)=d\left[1-\frac{1-h}{h} \frac{1-P_{2}}{P_{2}}\right]
$$

Equating these two expressions yields:

$$
\frac{1-a\left(1-P_{2}\right)}{P_{2}}=1-\frac{1-h}{h} \frac{1-P_{2}}{P_{2}}
$$

From this, we can calculate that:

$$
a=1+\frac{1-h}{h}
$$

This calculation offers a useful comparison of our model with Shleifer-Vishny (1997). It shows that leverage, particularly with thin haircuts, leads to massively more instability than there was in the original model. Recall that " $a$ " is the parameter reflecting the sensitivity of funds under management to performance, with the idea that it was a number like 1.1 or 1.2 . If $h=.2$, as we assumed in our example, then the implied “ $a$ " in the present model becomes equal to 5 , which means that liquidation spirals of assets are much more dramatic than in Shleifer-Vishny (1997).

\section{6: The financial crisis and economic policy}

In broad terms, the financial crisis of 2007-2009 can be easily outlined. The proximate cause of the crisis is the collapse of the housing bubble in the United States. The US home prices tripled between mid 1990s and 2006, and then fell spectacularly by perhaps some thirty percent in the last two years (Case 2008, Mayer et al. 2009). The housing bubble was accompanied by a major credit expansion, particularly in the 
residential mortgage area, but also in corporate loans, commercial mortgages, and credit card finance. Mortgages and other loans were to a very significant extent securitized, by pooling portfolios of loans together, tranching them into securities with different risks, and then selling them off (Coval et al. 2009). Securitization was a major financial innovation driven largely by huge demand for AAA securities by insurance companies, money market funds, and other investors (Benmelech and Dlugosz 2009). The enormous demand for mortgage-related securities also led to some decline in lending standards, and perhaps to misleading ratings of these securities by the rating agencies (Keys et al. 2008, Mian and Sufi 2009). Banks were intimately involved in both underwriting these securities, and holding large inventories on their own books. Banks financed these inventories of mortgage-related securities, at least in part, through short term borrowing. Thanks to these activities, bank profits and employee compensation grew spectacularly between 2002 and 2007.

As the housing bubble collapsed, mortgages began to default. Starting in the summer of 2007, we saw rapid declines in prices of mortgage-related securities, including AAA-rated bonds often used as collateral against short term loans. This price collapse effectively ended new securitization. With rapidly falling prices, banks sold off their inventories of securities very slowly. Some banks may have even increased credit risk exposure through derivatives such as credit default swaps and indices such as ABX. As the banks maintained their exposure to mortgage-related debt, real lending declined in nearly all categories, and not just in areas where securitization was prevalent (Ivashina and Scharfstein 2008). In 2008, the Federal Reserve Bank and then the US Treasury stepped into the crisis by first lending massively to banks against collateral, and then 
moving to equity injections (Veronesi and Zingales 2008). These expensive rescue attempts did not at least initially unfreeze bank lending to businesses. Rather, banks hoarded cash (in the form of deposits at the Federal Reserve) and tried to hold on to their inventories of securities.

Our model does not have anything to say about the housing bubble, but it does speak to every remaining key aspect of the narrative. Perhaps most important, the model suggests that the banks got themselves into so much trouble not by their irrationality or herding instincts, but by taking advantage of extraordinary temporary profit opportunities afforded by securitization. This is not to say that the banks correctly anticipated the depth of the crisis, and the troubles that were about to beset them (Gerardi et al 2008). Rather, the model suggests that liquid markets created tremendous opportunities for banks, and profit maximization pushed banks to take them. This is our interpretation of the now-famous quote of Chuck Prince, then Chairman of Citigroup: "When the music stops, in terms of liquidity, things will be complicated. But, as long as the music is playing, you've got to get up and dance. We are still dancing.” (Financial Times,7/9/07).

From the point of view of policy analysis, the model suggests two broad themes. First, the model identifies a fundamental instability of universal banking. Many economists have recognized the cyclicality of credit/risk-taking and the use of short-term debt as key factors contributing to the financial crisis. Some have attributed this behavior to agency problems within firms, inadequate monitoring or unhealthy competitive pressures to herd within the banking sector. We show that with modern banking the forces pushing toward cyclical credit expansion financed by short-term debt are much 
stronger than previously recognized. It will be difficult to wean the system of this behavior through better governance or improved regulatory capital measures.

Second, getting the economy out of trouble is likely to require addressing not just the liabilities of the banks, such as long term debt, but also their assets. So long as the banks continue to hold, and can choose to invest, in undervalued securities, the lending mechanisms will be blocked or weakened by the banks' own choice. This is true so long as securities trade at prices below their fundamental values. Unlocking the lending channel will require dealing directly with bank assets and not just their liabilities. 


\section{References}

Acharya,V., D. Gale and T. Yorulmazer, 2009. “Rollover Risk and Market Freezes,” Mimeo.

Adrian, T. and H. Shin, 2008. "Financial Intermediary Leverage and Value at Risk.” Federal Reserve Bank Staff Reports, 338.

Adrian, T. and H. Shin, 2009. "Money, Liquidity and Monetary Policy.” AER Papers and Proceedings, forthcoming.

Allen, F. and D. Gale, 1994. “Limited Market Participation and Volatility of Asset Prices.” American Economic Review, 84, 933-55.

Allen, F. and D. Gale, 1997. "Financial Markets, Intermediaries, and Intertemporal Smoothing,” Journal of Political Economy, 105, 523-546.

Allen, F. and D. Gale, 2000. “Bubbles and Crises.” Economic Journal, 110, 236-56.

Baker, M., and J. Wurgler, 2002. “Market Timing and Capital Strucutre.” Journal of Finance, 57, 1-32.

Baker, M., and J. Wurgler, 2004. “A Catering Theory of Dividends.” Journal of Finance $59,1125-1165$.

Baker, M., R. Ruback and J. Wurgler, 2007. "Behavioral Corporate Finance: A Survey.” Handbook in Corporate Finance: Empirical Corporate Finance, E. Eckbo (ed.)

Baker, M., J. Stein, and J. Wurgler, 2003. "When does the Market Matter? Stock Prices and Equity-Dependent Firms,” Quarterly Journal of Economics, 118, 969-1005.

Barro, R.,1990. “The Stock Market and Investment.” Review of Financial Studies,3, 115 $-132$.

Benmelech, E. and N. Bergman, 2009. “Credit Traps.” Mimeo. 
Benmelech, E. and J. Dlugosz, 2008. “The Alchemy of CDO Ratings.” Journal of Monetary Economics, forthcoming

Bernanke, B. and M. Gertler, 1989. “Agency Costs, Net Worth and Business Fluctuations.” American Economic Review, 79, 14-31.

Blanchard, O., C. Rhee, and L. Summers, 1993. “The Stock Market, Profit, and Investment.” Quarterly Journal of Economics, 108, 115-136.

Brunnermeier, M., 2009. “Deciphering the Liquidity and Credit Crunch 2007-2008.” Journal of Economic Perspectives, 23, 77-100.

Brunnermeier, M. and L. Pedersen, 2009. "Market Liquidity and Funding Liquidity.” Review of Financial Studies, forthcoming.

Caballero, R. and A. Krishnamurthy, 2008. "Collective Risk Management in a Flight to Quality Episode,” Journal of Finance, 63, 2195-2230.

Case, K., 2008. "The Central Role of House Prices in the Current Financial Crisis: How Will the Market Clear?,” Brookings Papers on Economic Activity, forthcoming.

Coval, J., J. Jurek, and E. Stafford, 2009. "The Economics of Structured Finance.” Journal of Economic Perspectives, 23, 3-26.

De Long, J.B., A. Shleifer, L. Summers, and R. Waldmann, 1989, “The Size and Incidence of the Losses from Noise Trading.” Journal of Finance, 44, 681-96.

De Long, A. Shleifer, L. Summers and, R. Waldmann, 1990. "Noise Trader Risk in Financial Markets.” Journal of Political Economy, 98, 703-38.

Diamond, D., 1984, “Financial Intermediation and Delegated Monitoring,” Review of Economic Studies, 51, 393-414.

Diamond, D. and P. Dybvig, 1983. “ Bank Runs, Deposit Insurance and Liquidity.” 
Journal of Political Economy, 91, 401-419.

Diamond, D. and R. Rajan, 2001. "Liquidity Risk, Liquidity Creation and Financial Fragility: A Theory of Banking,” Journal of Political Economy, 109, 287-327.

Diamond, D. and R. Rajan, 2009. “The Credit Crisis: Conjectures About Causes and Remedies.” AER Papers and Proceedings, forthcoming.

Diamond, D. and R. Rajan, 2009b, “Fear of Fire Sales and the Credit Squeeze,” Mimeo.

Farhi, E. and S. Panageas, 2006. "The Real Effects of Stock Market Mispricing at the Aggregate: Theory and Empirical Evidence.” Mimeo.

Farhi, E. and J. Tirole, 2008. “Competing Liquidities: Corporate Securities, Real Bonds and Bubbles.” Mimeo.

Fisher, I., 1933. “The Debt-Deflation Theory of Great Depressions.” Econometrica.

Fostel, A., and J. Geanakoplos, 2008. "Leverage Cycles and the Anxious Economy.” American Economic Review, 98, 1211-1244.

Gerardi, K, A. Lehnert, P. Willen, and S. Sherland, 2008. "Making Sense of the Subprime Crisis,” Brookings Papers on Economic Activity, forthcoming.

Gorton, G., 2008. “The Subprime Panic.” Mimeo.

Gorton, G. and G. Pennacchi, 1995. "Banks and Loan Sales: Marketing Non-Marketable Assets.” Journal of Monetary Economics, 35, 389-411.

Gorton, G. and N. Souleles, 2006. “Special Purpose Vehicles and Securitization.” In The Risks of Financial Institutions, R. Stulz and M. Carey (eds.).

Gorton, G. and A. Winton, 2003. "Financial Intermediation: A Survey.” in Handbook of the Economics of Finance, G. Constantinides, M. Harris, and R. Stulz (eds.).

Gromb, D. and D. Vayanos, 2002. "Equilibrium and Welfare in Markets with Financially 
Constrained Arbitrageurs.” Journal of Financial Economics, 66, 361-407.

Hart, O., and J. Moore. 1998. "Default and Renegotiation: A Dynamic Model of Debt,” Quarterly Journal of Economics, 113, 1-41.

He, Z., and A. Krishnamurthy, 2008. “A Model of Capital and Crises,” Mimeo.

Holmstrom, B. and J. Tirole, 1997. "Financial Intermediation, Loanable Funds, and the Real Sector.” Quarterly Journal of Economics, 112, 35-52.

Ivashina, V. and D. Scharfstein, 2008. "Bank Lending During the Financial Crisis of 2008.” Mimeo.

Kaplan, S. and J. Stein, 1993. “ The Evolution of Buyout Pricing and Financial Structure in the 1980s." Quarterly Journal of Economics, 108, 313-358.

Kashyap, A., R. Rajan and J. Stein, 2002. "Banks as Liquidity Providers: An Explanation for the Co-Existence of Lending and Deposit-Taking." Journal of Finance, 57, 33-73.

Keynes, J.M., 1936. The General Theory of Employment, Interest, and Money. London: Macmillan.

Keys, B., T. Mukherjee, A. Seru, and V. Vig, 2008. “ Did Securitization Lead to Lax Screening? Evidence from Subprime Loans.” Mimeo.

Kiyotaki, N. and J. Moore, 1997. “ Credit Cycles.” Journal of Political Economy, $105,211-248$.

Lamont, O. and J. Stein, 2006. "Investor Sentiment and Corporate Finance: Micro and Macro.” American Economic Review Papers and Proceedings, 96, 147-151.

Mayer, C., K. Pence, and S. Sherlund, 2009. “The Rise in Mortgage Defaults.” Journal of Economic Perspectives, 23, 27-50. 
Mian, A. and A. Sufi, 2009. "The Consequences of Mortgage Credit Expansion: Evidence from the US Mortgage Default Crisis.” Quarterly Journal of Economics, forthcoming.

Minsky, H., 1986. Stabilizing an Unstable Economy.

Morck, R., A. Shleifer, and R. Vishny, 1990. “The Stock Market and Investment: Is the Market a Sideshow?” Brookings Papers on Economic Activity, 2, 157-215.

Polk, C. and P. Sapienza, 2009. “The Stock Market and Corporate Investment: A Test of Catering Theory.” Review of Financial Studies, 22, 187-217.

Rajan, R., 2006. “Has Financial Development Made the World Riskier?” European Financial Management, 12.

Shleifer, A. and R. Vishny, 1992. “Liquidation Values and Debt Capacity: A Market Equilibrium Approach.” Journal of Finance, 47, 1343-66.

Shleifer, A. and R. Vishny, 1997. “ The Limits of Arbitrage.” Journal of Finance, 52, 35-55.

Stein, J., 1996. “Rational Capital Budgeting in an Irrational World.” Journal of Business, 69, 429-55.

Sufi, A., 2007. “Information Asymmetry and Financing Arrangements: Evidence from Syndicated Loans.” Journal of Finance, 62, 629-668.

Ventura, J., 2003. “Economic Growth with Bubbles.” Mimeo.

Veronesi, P. and L. Zingales, 2008. “Paulson’s Gift.” Mimeo.

Williamson, O., 1988. “Corporate Finance and Corporate Governance.” Journal of

Finance, 43, 567-92. 